\title{
Identification of virus and nematode resistance genes in the Chilota Potato Genebank of the Universidad Austral de Chile
}

\author{
Marlon López ${ }^{1}$, Ricardo Riegel², Carolina Lizana², and Anita Behn²*
}

Potato Genebank of the Universidad Austral de Chile (UACh) is an important gene bank in Chile. The accessions collected all over the country possess high genetic diversity, present interesting agronomic and cooking traits, and show resistance to biotic and abiotic stress. A particularly interesting subgroup of the gene bank includes the accessions collected in the South of Chile, the Chilota Potato Genebank. The focus of this study is the identification of virus and nematode resistant genes in potatoes (Solanum tuberosum L.), using the RYSC3 and YES3-3B molecular markers. The Potato virus $Y$ (PVY) resistance genes $R y_{\text {adg }}$ and $R y_{\text {sto }}$ were identified. Furthermore, the CP60 marker was used to assess the $R x$ resistance gene that confers resistance to Potato virus $X$ (PVX). In addition, the HC and GRO1-4 markers were utilized to identify the $G p a V_{v r n}$ QTL and Gro1-4, resistance genes of Globodera pallida and Globodera rostochiensis, respectively. Both G. pallida and G. rostochiensis are Potato Cyst Nematodes (PCN). The plant material used in this study included leaves from 271 accessions of the gene bank. These samples were collected in the field where natural pathogen pressure of potential viruses and diseases exists. ELISA assays were run for field detection of PVY and PVX. However, there have been no previous reports of nematode presence in the plant material. The results herein presented indicate presence of virus and nematode resistance genes in accessions of the Chilota Potato Genebank. In terms of virus resistance, 99 accessions out of the 271 tested possess the $R y_{\text {adg }}$ resistance gene and 17 accessions of these 271 tested have the $R y_{\text {sto }}$ resistance gene. Also, 10 accessions showed positive amplification of the $R x 1$ resistant gene marker. As to nematode resistance, 99 accessions have possible resistance to G. pallida and 54 accessions show potential resistance to G. rostochiensis as detected using the available molecular markers.

Key words: Globodera, molecular marker, Solanum tuberosum, PVY, PVX.

\section{INTRODUCTION}

Pests and diseases are the major threat to potato (Solanum tuberosum L.) cultivation worldwide. Specifically, these threats are most catastrophic on smallholder farms in less developed countries where certified seed potatoes and chemical protection are not generally accessible (Gebhardt et al., 2006). It is known that $30 \%$ of the world potato yield is lost due to pests and diseases (Jellis and Boulton, 1984). Worldwide, there are 50 viruses that could infect Solanum species and at least 60 nematode species affecting the potato crop (Salazar, 1995). Classical breeding for pest resistant crops involves the identification of resistant sources, which are often found in wild and unadapted germplasm. Once these resistant sources have been found, introgression of the resistance factors into cultivars

${ }^{1}$ Fundación Hondureña de Investigación Agrícola (FHIA), Apartado Postal 2067, San Pedro Sula, Cortés, Honduras.

${ }^{2}$ Universidad Austral de Chile, Facultad de Ciencias Agrarias, campus Isla Teja $\mathrm{s} / \mathrm{n}$, Valdivia, Chile.

*Corresponding author (anita.behn@uach.cl).

Received: 7 August 2014.

Accepted: 16 April 2015.

doi:10.4067/S0718-58392015000400008 is facilitated by repeated backcrossing to different $S$. tuberosum L. subsp. tuberosum clones. Following this, resistant progeny are phenotypically selected (Ross, 1986). Some of the known resistance factors have been located on molecular linkage maps using DNA-based markers. These resistance factors were mapped either as major genes (R genes) or as quantitative trait loci (QTL) (Gebhardt y Valkonen, 2001). Molecular markers are useful for constructing linkage and transcriptome maps (Ritter et al., 2008). Molecular markers can also be used to locate monogenic and polygenic traits to allow for the efficient introgression and selection of individuals with specific characteristics already in the seedling stage (Ritter et al., 2009). The use of DNA markers and markerassisted selection (MAS) could increase the accuracy and efficiency of potato breeding programs (Bertrand et al., 2008).

Potato virus $Y$ (PVY, genus Potyvirus) is one of the most important viral pathogens of the cultivated potato, and it also affects other Solanaceae species such as tomato (Lycopersicon esculentum Mill.), tobacco (Nicotiana tabacum L.), and pepper (Capsicum annuum L.) (Brunt et al., 1996). PVY, which can cause crop losses up to $80 \%$, spreads through the use of infected tuberseeds, mechanical contact, and through more than 25 
aphid species in a non-persistent way. Different defense mechanisms of PVY have been described including extreme resistance based on major genes, tolerance, and hypersensitive responses (Bendahmane et al., 1999). Resistance to PVY has been reported in native potatoes (Valkonen et al., 1996). Several major genes such as $R y$ in $S$. tuberosum L. subsp. andigena (Juz. \& Bukasov) Hawkes $\left(R y_{\text {adg }}\right), R y_{\text {hou }}$ in $S$. hougasii Correll and $R y_{\text {sto }}$ in $S$. stoloniferum Schltdl. \& Bouché (Barker 1997) are known to confer resistance. Kasai et al. (2000) developed the RYSC3 polymerase chain reaction (PCR)-based marker that can be used for the detection of both the $R y_{\text {adg }}$ gene and the $\mathrm{Na}_{a d g}$ gene that function in the hypersensitive response to Potato virus A (PVA). Some years later, Song et al. (2005) mapped the $R y_{\text {sto }}$ gene on chromosome XII that co-segregates with the molecular marker STM0003. Song and Schwarzfischer (2008) developed the STS molecular markers YES3-A and YES3-B to co-localize the $\mathrm{Ry}_{\text {sto }}$ gene.

Potato virus $X(\mathrm{PVX})$ is one of the main viruses infecting potatoes worldwide; it can cause yield losses ranging from $5-20 \%$, depending up on the virus strain, the potato genotype, and if the infection occurs simultaneously with other viruses like PVY and PVA (Adams et al., 2004). The two dominant genes $R x l$ and $R \times 2$, located on the top arm of chromosome XII and the upper arm of chromosome $\mathrm{V}$, respectively, confer extreme resistance to PVX in potatoes (Bendahmane et al., 1997; Ritter et al., 1991).

There are several nematode species that affect potato crops. The Globodera genus is highly specific to Solanaceous species, and two Globodera species G.pallida and G. rostochiensis are found abundantly on potatoes. These are commonly known as potato cyst nematodes $(\mathrm{PCN})$ and reduce tuber yields due to a reduction in the tuber size (Mugniéry and Phillips, 2007). Both species of PCN can be divided into pathogenic variants or pathotypes. An effective and long-lasting way to control PCN is the use of resistant potato cultivars. The dominant gene Grol resistant to G. rostochiensis most likely originated from S. spegazzinii Bitter as this gene was mapped to potato chromosome VII (Barone et al., 1990). At the molecular level, the Grol locus consists of a clustered family of NBLRR type genes. One member of this family, Grol-4, was shown to confer resistance to $G$. rostochiensis pathotype Rol (Paal et al., 2004). Schwarzfischer et al. (2009) showed that the Grol-4 gene is informative for identifying varieties that possess full pathotype resistance to Rol-5 of G. rostochiensis. The most prominent and reproducible QTL for G. pallida resistance has been mapped to chromosome V. The diagnostic value of using the linked DNA marker SPUD1636 to identify sources of resistance was demonstrated for some accessions of Solanum vernei Bitter \& Wittm (Bryan et al., 2002). Following this, Sattarzadeh et al. (2006) reported that the PCR marker $\mathrm{HC}$ has a higher diagnostic value for identifying resistance in G. pallida. Furthermore, Schwarzfischer et al. (2009) showed that HC is an appropriated diagnostic tool to identify resistance in a wide spectrum of German potato varieties.

The genetic pool of wild tuber-bearing species of Solanum has been and will still be used as a source of resistance to viruses and nematodes in potato breeding. The range of genes available from wild species will allow potato breeders to combat pests and diseases in the future (Contreras and Tapia, 1983). The Chiloe Province in southern Chile, is considered to be a sub-center of the origin of potato species. The Potato Genebank at the Universidad Austral de Chile has a large number of accessions collected from the Chiloe Province, and therefore this repository most likely houses important genetic resources, including specific genes and genomic regions that can be used to look for pest and disease resistance. The objective of this study was to determine the existence of resistance alleles to Potato virus Y, Potato virus $X$, and potato cyst nematodes (PCN), Globodera pallida and G. rostochiensis. Here conventional molecular markers and accessions of the Chilota Potato Genebank exposed to the natural pressure of viruses and nematodes were used.

\section{MATERIAL AND METHODS}

\section{Plant material}

Two hundred and seventy one accessions of the working collection of the Chilota Potato Genebank of the UACh maintained on the Southern Agricultural Experiment Station in Valdivia, Chile, were tested. The Potato Genebank was founded in 1958 at the university (UACh) when the Chilean Ministry of Agriculture donated potato accessions. Since then, the collection has been cultivated yearly at the Southern Agricultural Experiment Station of the UACh. The collection grew further due to many nationwide excursions conducted by Prof. Andrés Contreras and others. The colored tetraploid potatoes collected in the Chiloe Province were utilized for this study. Most of these potatoes are well described in recompilations of Contreras and Castro (2008).

The samples used in this study were collected from the experimental fields of the UACh and were not inoculated with viruses or nematodes so that the natural pressure of potential viruses and other diseases could be considered.

\section{Serological procedure}

Serological ELISA tests were used to determine the presence of PVY and PVX. The sap of fresh leaves from the 271 samples was extracted by mechanically (reductor machine R52 DT71K4/2, SEW EURODRIVE, Bruchsal, Germany) crushing five leaves of each accession while adding an extraction buffer. The procedure followed the protocol of BIOREBA for virus identification though some modifications were made. The BIOREBA (Reinach, 
Switzerland) PVY polyclonal and PVX monoclonal reagent sets were used.

\section{DNA extraction and quantification}

Plant DNA was obtained from fresh leaves of five different plants of each accession collected from the field. Leaves were processed with the protocol described by Doyle and Doyle (1990) with some modifications. The quantification of the genomic DNA was performed using a 16-well Infinite F200/M200 NanoQuant spectrophotometer (TECAN, Männedorf, Switzerland) with absorption wavelengths of 260 and $280 \mathrm{~nm}$. The DNA concentrations were diluted to $50 \mathrm{ng} \mathrm{uL}^{-1}$ DNA per sample.

\section{Diagnostic PCR marker assays}

PCRs were performed in a thermal cycler (MULTIGENE, International Labnet Inc., Edison, New Jersey, USA). The primers used in each assay are shown in Table 1. The reactions for amplifying the RYSC3 SCAR marker were performed in a final volume of $13 \mu \mathrm{L}$ following the protocol of Kasai et al. (2000). The reaction contained 1X buffer (INVITROGEN, Carlsbad, California, USA), 100 $\mu \mathrm{M}$ of each dNTP, $2 \mathrm{mM} \mathrm{MgCl}_{2}, 0.2 \mu \mathrm{M}$ of each forward and reverse primer, $1 \mathrm{U}$ of Taq polymerase (Invitrogen) and $50 \mathrm{ng}$ of genomic DNA. The PCR program consisted of an initial denaturation step at $93{ }^{\circ} \mathrm{C}$ for $9 \mathrm{~min}$, followed by 35 cycles of denaturation at $95^{\circ} \mathrm{C}$ for $45 \mathrm{~s}$, primer annealing at $52{ }^{\circ} \mathrm{C}$ for $45 \mathrm{~s}$ and primer extension at $72{ }^{\circ} \mathrm{C}$ for $1 \mathrm{~min}$, followed by a final extension at $72{ }^{\circ} \mathrm{C}$ for $10 \mathrm{~min}$. The negative control used was 'Desiree' (susceptible to PVY) and the positive control used was 'Eva' that possesses the $R y_{\text {adg }}$ gene and is immune to PVY, as described in Sagredo et al. (2009).

According to the protocol described by Song and Schwarzfischer (2008), the $R y_{\text {sto }}$ gene was detected using the YES3-3B STS marker. The optimum PCR band produced using this marker is $286 \mathrm{bp}$ in size. The reaction was performed in a final volume of $13 \mu \mathrm{L}$ containing $1 \mathrm{X}$ buffer (INVITROGEN), $100 \mu \mathrm{M}$ of each dNTP, $2 \mathrm{mM}$ $\mathrm{MgCl}_{2}, 0.2 \mu \mathrm{M}$ of each forward and reverse primer, $1 \mathrm{U}$ Taq polymerase (Invitrogen) and $50 \mathrm{ng}$ of genomic DNA. The PCR program consisted of an initial denaturation of $94{ }^{\circ} \mathrm{C}$ for $2 \mathrm{~min}$, followed by 10 cycles of denaturation at $94{ }^{\circ} \mathrm{C}$ for $40 \mathrm{~s}$, primer annealing at $60{ }^{\circ} \mathrm{C}$ for $40 \mathrm{~s}$ and primer extension at $72{ }^{\circ} \mathrm{C}$ for $1 \mathrm{~min}$, followed by 30 cycles of denaturation at $94^{\circ} \mathrm{C}$ for $40 \mathrm{~s}$, primer annealing at $55{ }^{\circ} \mathrm{C}$ for $40 \mathrm{~s}$, and primer extension at $72{ }^{\circ} \mathrm{C}$ for 1 min, followed for a final extension of $72{ }^{\circ} \mathrm{C}$ for $10 \mathrm{~min}$.
The negative control used was 'Desiree' (susceptible to PVY) and the positive control used was 'Amado', which is immune to PVY (DNA of 'Amado' was kindly provided by Dr. A. Schwarzfischer, Bavarian State Research Center for Agriculture, Institute for Crop Science and Plant Breeding, 2012).

The Rxl gen was identified using the CP60 CAPS marker after restriction digestion with enzyme DdeI according to Bendahmane et al. (1997). A 350 bp DdeI fragment was indicative of positive $R x l$ presence in the accessions with resistance to PVX. The PCR reaction was performed in a final volume of $40 \mu \mathrm{L}$ containing $1 \mathrm{X}$ buffer, $100 \mu \mathrm{M}$ of each dNTP, $2 \mathrm{mM} \mathrm{MgCl}_{2}, 0.2 \mu \mathrm{M}$ of each forward and reverse primer, $1 \mathrm{U}$ Taq polymerase and $50 \mathrm{ng}$ genomic DNA. The PCR program consisted of an initial denaturation step of $94{ }^{\circ} \mathrm{C}$ for $4 \mathrm{~min}$, followed by 35 cycles of denaturation at $94{ }^{\circ} \mathrm{C}$ for $45 \mathrm{~s}$, primer annealing at $60^{\circ} \mathrm{C}$ for $45 \mathrm{~s}$ and primer extension at $72{ }^{\circ} \mathrm{C}$ for $45 \mathrm{~s}$, followed by a final elongation at $72{ }^{\circ} \mathrm{C}$ for 10 min. The negative control used was 'Desiree' (susceptible to PVX) and the positive control used was 'Atlantic'.

The Grol-4 gen was identified using the Gro1-4 SCAR marker described by Paal et al. (2004), which generates an amplification product of $602 \mathrm{bp}$ and is associated with resistance to $G$. rostochiensis The PCR reaction was performed in a final volume of $13 \mu \mathrm{L}$ containing $1 \mathrm{X}$ buffer, $100 \mu \mathrm{M}$ of each dNTP, $2 \mathrm{mM} \mathrm{MgCl}_{2}, 0.2 \mu \mathrm{M}$ of each forward and reverse primer, $1 \mathrm{U}$ Taq polymerase and $50 \mathrm{ng}$ of genomic DNA. The PCR program consisted of an initial denaturation of $94^{\circ} \mathrm{C}$ for $3 \mathrm{~min}$, followed for 35 cycles of denaturation at $92{ }^{\circ} \mathrm{C}$ for $45 \mathrm{~s}$, primer annealing at $52{ }^{\circ} \mathrm{C}$ for $45 \mathrm{~s}$, and primer extension at $72{ }^{\circ} \mathrm{C}$ for 1 min, and a final step at $72{ }^{\circ} \mathrm{C}$ for $10 \mathrm{~min}$. The positive and negative controls were the same as those used for the $\mathrm{HC}$ marker.

The HC primers described by Sattarzadeh et al. (2006) generate a specific amplification product of $276 \mathrm{bp}$ for the QRL-HC locus associated with resistance to G. pallida. The PCR reaction was performed in a final volume of $13 \mu \mathrm{L}$ contained $1 \mathrm{X}$ buffer, $100 \mu \mathrm{M}$ each dNTP, $2 \mathrm{mM}$ $\mathrm{MgCl}_{2}, 0.2 \mu \mathrm{M}$ of each forward and reverse primer, $1 \mathrm{U}$ Taq polymerase and $50 \mathrm{ng}$ of genomic DNA. The PCR program consisted of an initial denaturation step of $94{ }^{\circ} \mathrm{C}$ for $4 \mathrm{~min}$, followed by 35 cycles of denaturation at $94^{\circ} \mathrm{C}$ for $45 \mathrm{~s}$, primer annealing at $60{ }^{\circ} \mathrm{C}$ for $45 \mathrm{~s}$ and primer extension at $72{ }^{\circ} \mathrm{C}$ for $45 \mathrm{~s}$, followed by a final elongation at $72{ }^{\circ} \mathrm{C}$ for $10 \mathrm{~min}$. The negative control used was 'Desiree', susceptible to G. pallida and G. rosotochiensis.

Table 1. Molecular markers used and their primer sequences.

\begin{tabular}{|c|c|c|c|c|c|}
\hline Marker & $\begin{array}{l}\text { Type/ } \\
\text { restriction }\end{array}$ & Gene & $\begin{array}{l}\text { Size } \\
\text { (bp) }\end{array}$ & Primers 5'-3' & Reference \\
\hline RYSC3 & SCAR & $R y_{a d g}$ & 321 & ATACACTCATCTAAATTTGATGG AGGATATACGGCATCATTTTTCCG & Kasai et al. (2000) \\
\hline YES3-3B & STS & $R y_{\text {sto }}$ & 290 & TAACTCAAGCGGAATAACCC CATGAGATTGCCTTTGGTTA & Song and Schwarzfischer (2008) \\
\hline CP60 & CAPS/DdeI & $R x 1$ & 350 & CAGCCTACCGCGAAAGTGCCTTCG GCCAACCCCACGAGTTTCTCACTGAC & Bendahmane et al. (1997) \\
\hline Gro1-4 & SCAR & Grol-4 & 602 & TCTTTGGAGATACTGATTCTCA CGACCTAAAATGAAAAGCATCT & Paal et al. (2004) \\
\hline $\mathrm{HC}$ & SNP & $G p a V_{v r n} Q T L$ & 276 & ACACCACCTGTTTGATAAAAACT GCCTTACTTCCCTGCTGAAG & Sattarzadeh et al. (2006) \\
\hline
\end{tabular}


'Brisant' was used as a positive control as it is immune to G. pallida and G. rosotochiensis (DNA of 'Brisant' was kindly provided by Dr. A. Schwarzfischer, Bavarian State Research Center for Agriculture, Institute for Crop Science and Plant Breeding, 2012).

\section{RESULTS}

\section{Resistance to PVY, PVX, and Globodera spp.}

To determine the presence of the $R y_{a d g}$ and $R y_{\text {sto }} \mathrm{PVY}$ resistance genes, the RYSC3 SCAR marker and the YES3-3B STS marker were used, respectively. Ninety nine accessions out of the 271 showed amplification of the RYSC3 marker associated with resistance to PVY in $S$. tuberosum subsp. andigena source (Figure 1). Seventeen accessions showed amplification of the YES3-3B marker associated with resistance to PVY in S. stoloniferum (Figure 1). Finally, there were seven accessions that had amplification for both markers associated with PVYresistance.

In resistance to PVX, the CP60 CAPS marker was used to locate the $R x l$ gene, which confers resistance to PVX. Ten accessions showed successful amplification of a $350 \mathrm{bp}$ product (Figure 1). Due to difficulties in the amplification of the PCR product only $57 \%$ of the accessions of the gene bank were assessed.

In resistance to Globodera spp., the Gro1-4 SCAR marker and the HC SNP marker were used to locate the Grol-4 gene and the GpaV $V_{v r n}$ QTL, which are resistance genes to $G$. rostochiensis and $G$. pallida, respectively (Figure 2). Positive amplification of the Grol-4 gene associated with resistance to G. rostochiensis was possible in 54 accessions and in 99 accessions the $\mathrm{HC}$ marker related to resistance to G. pallida was amplified.

\section{Combined resistance}

As gene pyramiding is an important tool to enhance the development of new potato varieties, the marker combinations used in this study should be considered in further breeding experiments. In the present analysis, one accession was found to possess both markers for
A

Gro1-4 marker
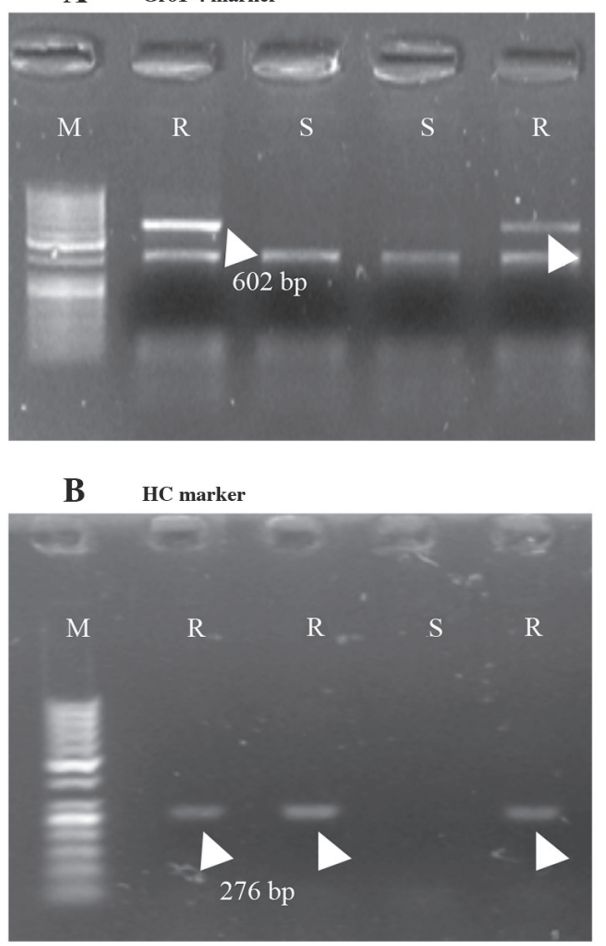

Thicker bands represent 250 and 500 bp; $\mathrm{R}=$ resistant; $\mathrm{S}=$ susceptible.

Figure 2. Examples of amplification products and diagnostic bands (with arrow) in potato accessions with markers associated with nematode resistance A) Gro1-4 marker associated with resistance to Globodera rostochiensis (Paal et al., 2004); HC marker for G. pallida resistance (Sattarzadeh et al., 2006). $M=50$ bp DNA ladder (Thermo Scientific).

PVY and for nematode resistance. Amplification using the diagnostic markers RYSC3, YES3-3B, GRO14, and HC was possible for accession 97-AU-1296. Furthermore, two other accessions showed positive amplification products for the YES3-3B, Gro1-4, and HC markers. In addition, amplification of three molecular markers (GRO1-4, HC, and RYSC3) was possible for eight accessions. Finally, the RYSC3 and HC molecular markers produced positive amplification in 34 accessions.
A RYSC3 marker

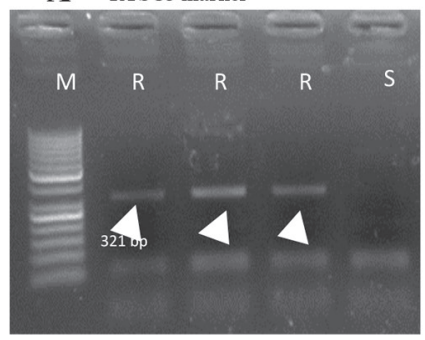

B YES3-3B marker

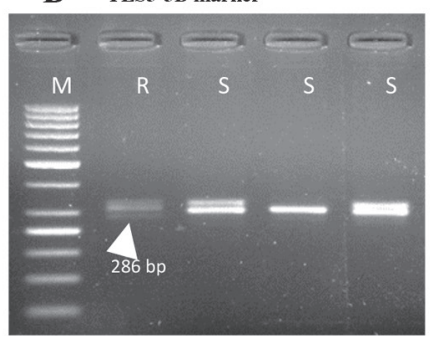

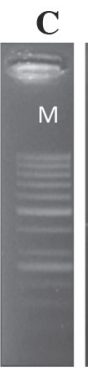

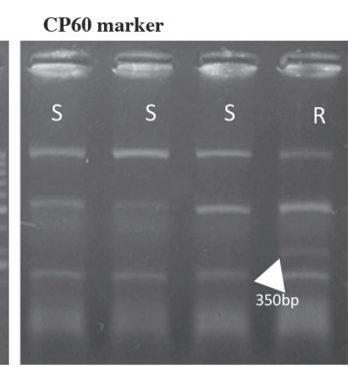

Thicker bands represent 250 and 500 bp; $\mathrm{R}=$ resistant; $\mathrm{S}=$ susceptible.

Figure 1. Examples of amplification products and diagnostic bands (with arrow) in potato accessions with markers associated with virus resistance: A) RYSC3 marker for Potato virus Y (PVY) resistance $\left(\mathrm{Ry}_{\text {adg }}\right)$ (Kasai et al., 2000); B) YES3-3B marker for PVY resistance ( $\mathbf{R y}_{\text {sto }}$ ) (Song and Schwarzfischer, 2008); C) CP60 marker associated with Potato virus $X$ (PVX) resistance (Bendahmane et al., 1997). M = 50 bp DNA ladder (Thermo Scientific). 
These two markers are associated with resistance to PVY and G. pallida, respectively. The GRO1-4 marker related to $G$. rostochiensis resistance and the RYSC3 marker for PVY resistance were used for successful amplifications in ten accessions. Specifically, one accession showed amplification for the markers RYSC3, CP60, and HC, one for CP60, GRO1-4, HC. Two accessions showed positive amplification for the CP60 and HC markers, and amplification using the RYSC3 and CP60 markers was possible for one accession (Table 2).

\section{Serological and molecular results}

The ELISA tests were additional to the molecular results. Figure 3 shows all accessions evaluated, including the accessions without marker amplification. From the 271 evaluated accessions, 247 showed negative ELISA results

Table 2. Accessions with a combination of two or more amplified molecular markers.

\begin{tabular}{|c|c|c|c|c|c|c|}
\hline Accession & RYSC3 & YES3-3B & CP60 & GRO1-4 & $\mathrm{HC}$ & Resistance genes \\
\hline 280-CON-755 & + & + & - & $(+)$ & - & $R y_{a d g}, R y_{s t o}$, Grol-4 \\
\hline 366-UA-1186A & + & + & - & - & - & $R y_{\text {adg }}, R y_{\text {sto }}$ \\
\hline 521-UA-1625B & + & + & - & - & - & $R y_{a d g}, R y_{\text {sto }}$ \\
\hline 97-UA-1296 & + & + & - & + & + & $R y_{\text {adg }}, R y_{\text {sto }}$, Grol-4, GpaV $V_{v r n} Q T L$ \\
\hline 233-UA-1593 & - & + & - & + & + & $R y_{s t o}$, Gro1-4, GpaV ${ }_{v r n} Q T L$ \\
\hline 530-CON-1114 & - & + & - & + & + & $R y_{s t o}$, Gro1-4, GpaV $V_{v r n-} Q T L$ \\
\hline 254-CON-902 & + & - & - & + & + & $R y_{a d g}$, Grol-4, GpaV Vrrn- $Q T L$ \\
\hline 219-UA-1534 & + & - & - & + & + & $R y_{\text {adg }}$, Gro1-4, GpaV $V_{v r n-} Q T L$ \\
\hline 4-CON-1154 & + & - & - & + & + & $R y_{\text {adg }}$, Grol-4, GpaV Vrrn-QTL \\
\hline 247-CON-1100 & + & - & - & + & + & $R y_{\text {adg }}$, Grol-4, GpaV $V_{v r n} Q T L$ \\
\hline NG-117 & + & - & - & + & + & $R y_{a d g}$, Gro1-4, GpaV Vrn_ $Q T L$ \\
\hline NG-82 & + & - & - & + & + & $R y_{a d g}$, Gro1-4, GpaV Vrn_ $Q T L$ \\
\hline INIA-S/N-P1 & + & - & - & + & + & $R y_{\text {adg }}$, Grol-4, GpaV Vrn_QTL \\
\hline 373-UA-1587 & + & - & - & - & + & $R y_{a d g}, G p a V_{v r n-} Q T L$ \\
\hline $\mathrm{NN}-1$ & + & - & - & - & + & $R y_{a d g}, G p a V_{v r n} Q T L$ \\
\hline 93-COCHRANE-14 & + & - & - & - & + & $R y_{a d g}, G p a V_{v r n-} Q T L$ \\
\hline 244-CON-1266 & + & - & - & - & + & $R y_{a d g}, G p a V_{v r n} Q T L$ \\
\hline 344-CON-1148 & + & - & - & - & + & $R y_{\text {adg }}, G p a V_{v r n=} Q T L$ \\
\hline 418-UA-1243 & + & - & - & - & + & $R y_{a d g}, G p a V_{v r n} Q T L$ \\
\hline 298-UA-1362 & + & - & - & - & + & $R y_{a d g}, G p a V_{v r n} Q T L$ \\
\hline 229-CON-1039 & + & - & - & - & + & $R y_{a d g}, G p a V_{v r n} Q T L$ \\
\hline 205-UA-1014 & + & - & - & - & + & $R y_{a d g}, G p a V_{v r n \_} Q T L$ \\
\hline 227-CON-824 & + & - & - & - & + & $R y_{a d g}, G p a V_{v r n-} Q T L$ \\
\hline 166-CON-1089 & + & - & - & - & + & $R y_{a d g}, G p a V_{v r n} Q T L$ \\
\hline 181-UA-1022 & + & - & - & - & + & $R y_{a d g}, G p a V_{v r n-} Q T L$ \\
\hline 161-CON-1093 & + & - & - & - & + & $R y_{a d p}, G p a V_{v r n-} Q T L$ \\
\hline 487-UA-1191 & + & - & - & - & + & $R y_{a d g}, G p a V_{v r n=} Q T L$ \\
\hline 93-COCHRANE-13 & + & - & - & - & + & $R y_{a d g}, G p a V_{v r n} Q T L$ \\
\hline 336-CON-784 & + & - & - & - & + & $R y_{a d g}, G p a V_{v r n-} Q T L$ \\
\hline 184-UA-1356 & + & - & - & - & + & $R y_{a d g}, G p a V_{v r n-} Q T L$ \\
\hline 481-CON-1099 & + & + & - & - & + & $R y_{\text {adg }}, R y_{s t o}, G p a V_{v r n-} Q T L$ \\
\hline NG-94 & + & - & - & - & + & $R y_{a d g}, G p a V_{v r n} Q T L$ \\
\hline 488-UA-1354 & + & - & - & - & + & $R y_{\text {adg }}, G p a V_{v r n-} Q T L$ \\
\hline 156-CON-1171 & + & - & - & - & + & $R y_{a d g}, G p a V_{v r n-} Q T L$ \\
\hline 512-UA-1079 & + & - & - & - & + & $R y_{a d g}, G p a V_{v r n-Q T L}$ \\
\hline NG-88 & + & - & - & - & + & $R y_{a d g}, G p a V_{v r n} Q T L$ \\
\hline 586-CON-1153 & + & + & - & - & + & $R y_{\text {adg }}, R y_{s t o}, G p a V_{v r n-} Q T L$ \\
\hline 93-COCHRANE-6 & + & - & - & - & + & $R y_{a d g}, G p a V_{v r n} Q T L$ \\
\hline 195-CON-1296 & + & - & + & - & + & $R y_{a d g}, R x, G p a V_{v r n} Q T L$ \\
\hline $133-\mathrm{CON}-1051$ & + & - & - & - & + & $R y_{a d g}, G p a V_{v r n} Q T L$ \\
\hline 185-UA- 1560 & + & - & - & - & + & $R y_{a d g}, G p a V_{v r n-} Q T L$ \\
\hline NG-120 & + & - & - & - & + & $R y_{a d g}, G p a V_{v r n-} Q T L$ \\
\hline 311-UA-1093 & + & - & - & - & + & $R y_{a d g}, G p a V_{v r n-} Q T L$ \\
\hline 421-CON-921 & + & - & - & - & + & $R y_{a d g}, G p a V_{v r n-} Q T L$ \\
\hline 422-UA-1023 & + & - & - & - & + & $R y_{a d g}, G p a V_{v r n} Q T L$ \\
\hline 563-UA-1157 & + & - & - & - & + & $R y_{a d g}, G p a V_{v r n} Q T L$ \\
\hline CARAHUE-CON-1365 & + & - & - & - & + & $R y_{a d g}, G p a V_{v r n} Q T L$ \\
\hline LOS LAGOS & + & - & - & - & + & $R y_{a d g}, G p a V_{v r n-} Q T L$ \\
\hline 58-CON-1041 & + & - & - & + & - & $R y_{a d g}$, Grol-4 \\
\hline 260-CON-917 & + & - & - & + & - & Ry adg, Grol-4 \\
\hline 169-UA-1517 & + & - & - & + & - & $R y_{\text {adg }}$, Grol-4 \\
\hline NG-92 & + & - & - & + & - & Ry adg, Grol-4 \\
\hline NG-80 & + & - & - & + & - & Ry adg, Grol-4 \\
\hline 585-UA-1633 & + & + & - & + & - & $R y_{\text {adg }}, R y_{s t o}$, Grol-4 \\
\hline 541-UA-1042 & + & - & - & + & - & $R y_{a d g}$, Grol-4 \\
\hline 562-UA-1397 & + & - & - & + & - & Ry adg, Grol-4 \\
\hline 547-UA-1053 & + & - & - & + & - & $R y_{\text {adg }}$, Grol-4 \\
\hline NG-140 & + & - & - & + & - & $R y_{\text {adg }}$, Grol-4 \\
\hline 426-CON-926 & - & - & + & + & + & $R x$, Grol-4, GpaV $V_{v r n} Q T L$ \\
\hline 464-UA-1360 & - & - & + & - & + & $R x, G p a V_{v r n} Q T L$ \\
\hline $195-\mathrm{CON}-1296$ & - & - & + & - & + & $R x, G p a V_{v r n} Q T L$ \\
\hline 42-UA-1258 & + & - & + & - & - & $R y_{a d g}, R x$ \\
\hline
\end{tabular}

$+=$ Marker presence $-=$ Marker absence. 
A

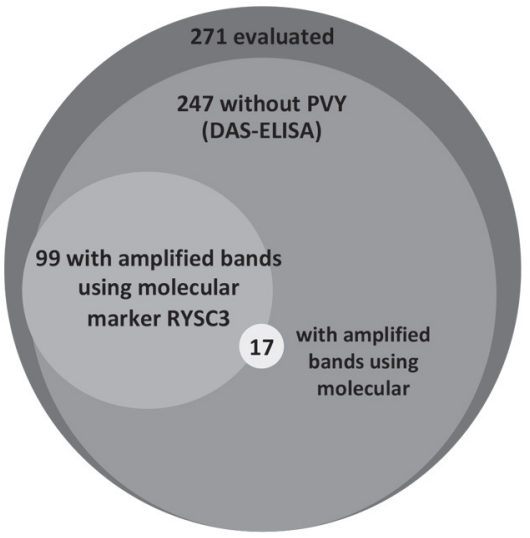

B

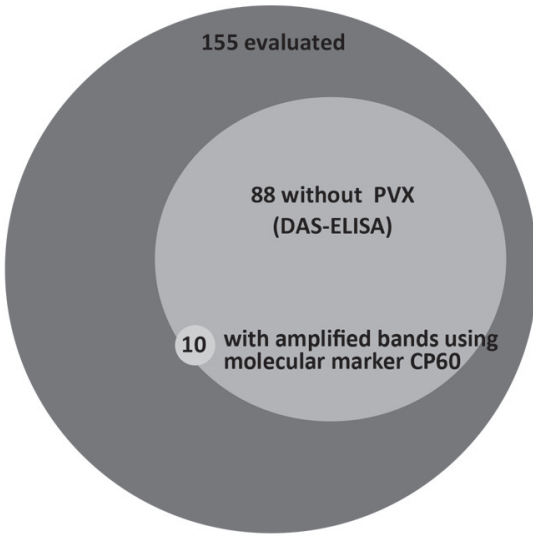

Figure 3. A) Number of accessions evaluated using markers RYSC3 and YES3-3B with and without virus infection according to the DASELISA results as well as presence and absence of both markers. B) Number of accessions analyzed with the CP60 marker with and without virus infection according to the DAS-ELISA results as well as presence and absence of the CP60 band.

for PVY presence, which means that $91 \%$ of the accessions from the field showed no PVY infestation. Ninety-nine accessions of the 247 accessions mentioned above showed positive amplification bands when the RYSC3 marker was used. In addition, 17 accessions showed positive amplification when the YES3-3B marker was used. Seven accessions showed negative ELISA results for PVY and negative PCR products for both of the PVY-resistance markers (RYSC3 and YES3-3B). The remaining 148 accessions (60\% of the accessions without PVY presence) showed no virus infection and no amplification was possible for any of the molecular markers.

Out of the 155 accessions evaluated for PVX presence, 67 showed PVX positive and 88 showed PVX negative ELISA results. Nine out of the 10 accessions that presented band amplifications using the CP60 marker had negative ELISA results.

\section{DISCUSSION}

For many years, the characteristics of the accessions of the UACh Chilota Potato Genebank have been evaluated.
Traits such as yield, disease resistance, potato flavor, and taxonomic classification (part of this information is available in the catalogue of Contreras and Castro (2008) and at www.potatogenebank.cl), have been investigated. However the present study is the first molecular marker evaluation of virus and nematode resistance in Chilota potatoes.

The utilization of the RYSC3 marker has been validated by many authors such as Dalla Rizza et al. (2006), Sagredo et al. (2009), Veramendi et al. (2011), Ortega and Lopez-Vizcon (2012), and Lopez-Pardo et al. (2013). In the evaluation of the 271 Solanum tuberosum subsp. tuberosum accessions, amplification using the RYSC3 marker was possible in 99 accessions. That means that $37 \%$ of the measured accessions possess the resistance marker. There are clear differences between $S$. tuberosum subsp. tuberosum and S. tuberosum subsp. andigena (Hawkes, 1990). However, the source of origin of these two subspecies has been delimited geographically and both subspecies seem to have co-evolved together and genes resistant to viruses and nematodes are present in both subspecies.

The S. stoloniferum $\left(R y_{\text {sto }}\right)$ PVY resistance was first reported by Cockerham (1943). This gene confers resistance to all strains of PVY and PVA (Ross, 1986; Barker, 1997). The YES3-3B molecular marker has been used by breeders in Europe. Lindner et al. (2011) used YES3-3A and YES3-3B for evaluation of PVY in German potato varieties showing that 21 of the 31 varieties evaluated possess $R y_{\text {sto }}$, the gene for resistance. By evaluating tetraploid crosses of S. phureja, Schwarzfischer et al. (2009) found 10 varieties of potato with extreme resistance to PVY. In the present study, 17 accessions were found to have an amplified gene product using the YES3-3B marker. Although the geographical origin of $S$. stoloniferum and S.tuberosum ssp.tuberosum seems to be different, some S. tuberosum ssp. tuberosum accessions of the Potato Genebank possess the same loci for resistance as $S$. stoloniferum. This situation might be explained by ancestral history.

The marker RYSC3 produced positive amplification for the following accessions: 525-UA-1244, 236-UA1031, 502-UA-1071, 512-UA-1079, and 181-UA-1022. These accessions were reported to have absence of PVY according to the DAS-ELISA. In various publications (Contreras and Banse, 1982; Contreras and Tapia, 1983), these accessions have been shown to lack PVY, therefore it seems to be accessions with a PVY resistance, lasting through the time. Out of the 99 accessions the amplified for the marker RYSC3, 95 showed absence of PVY according to DAS-ELISA. These represent a 95\% correlation between molecular and serological results. Both methods are usually applied as a tool for virus resistances evaluations; like Gebhardt et al. (2006), Sagredo et al. (2009), and Ortega and Lopez-Vizcon (2012). The remaining 148 accessions showed no virus 
infection and no molecular marker amplification, task that might be explained by unknown PVY resistance sources, since that plant has been exposed to natural pest presence on the field.

An important number of wild Solanum species have been used as resistance source for PVX. The $R x_{\text {adg }}(R x l)$, $R x_{t b r}, R x_{a c l}(R x 2)$ genes conferring extreme resistance to PVX have been reported in $S$. tuberosum subsp. andigena, S. tuberosum L. subsp. chiloense (A. DC.) L.I. Kostina and S. acaule (Cockerham, 1970). Bendahmane et al. (1997) localized the Rxl gene on chromosome XII, using the GP34 and CP60 molecular markers. The CP60 marker has been used by other authors such as Gebhardt et al. (2006) and Veramendi et al. (2011). Comparing the same accessions used in this investigation that showed amplification using the CP60 marker, with previous evaluations of the Potato Genebank, Contreras and Banse (1982) reported that accessions 548-UA-1328, 464-UA1360, and 186-UA-1045 are not resistant to PVX as determined by serological evaluation.

The genes resistant to PCN have been reported in $S$. spegazzinii and S. vernei (Ross, 1986; Phillips, 1994). The HC and Gro1-4 molecular markers associated with resistance to PCN were used by other authors: Gebhardt et al. (2006), Veramendi et al. (2011), Milczarek et al. (2011), Ortega and Lopez-Vizcon (2012), Lopez-Pardo et al. (2013), Dalton et al. (2013). In this study 99 accessions (36\% of the 271 accessions) showed amplification bands using the $\mathrm{HC}$ marker. In addition, 54 accessions (20\% of 217 accessions) showed positive amplification products for marker Gro1-4. This result is promising considering that fewer accessions were expected to amplify for these markers, because of previous information about the accessions and the impossibility of co-evolution of the disease with the potato crop due to the absence of $G$. rostochiensis in the South of Chile. The PCN is considered a quarantine pest in European and Mediterranean Plant Protection Organization (EPPO) member countries and in seed potato growing areas of Chile (SAG, 2008). Therefore, nematode resistance genes for G. pallida and $G$. rostochiensis have a great relevance in the potato breeding programs all over the world.

Milla and Krausz (2004) found three accessions with extreme PCN resistance, three accessions with partial resistance, and eight accessions susceptible in a preview evaluation of 14 accessions of the Potato Genebank. From the accessions with extreme resistance, two accessions (280-CON-755 and 254-CON-902) amplified for the Gro1-4 marker in this study. Further studies will test other molecular markers for PCN resistances as well as inoculation tests of resistant accessions in the lab.

\section{CONCLUSIONS}

Molecular markers linked to resistance genes for the PVY, PVX and Potato Cyst Nematode (PCN) were found within the Chilota Potato Genebank of the Universidad Austral de Chile. As all of the used markers are known to be linked to major genes, they are a real tool to be used for gene pyramiding in further potato breeding programs. The PVY resistance genes of Solanum tuberosum subsp. andigena $\left(R y_{a d g}\right)$ were found in a higher proportion than those of Solanum stoloniferum $\left(R y_{\text {sto }}\right)$. The genes resistant to PCN were found in a greater proportion for Globodera pallida than for $G$. rostochiensis. However, there were also accessions found that possess both resistance genes. The tested accessions are highly recommended for potato crop breeding as they possess resistance to diseases and pathogens relevant at national and global scales.

\section{ACKNOWLEDGEMENTS}

This work was funded by the DID 2012-03 project from the Universidad Austral de Chile.

\section{LITERATURE CITED}

Adams, M.J., J.F. Antoniw, M. Bar-Joseph, A.A. Brunt, T. Candresse, G.D. Foster, et al. 2004. The new plant virus family Flexiviridae and assessment of molecular criteria for species demarcation. Archives of Virology 149:1045-1060.

Barker, H. 1997. Extreme resistance to potato virus V in clones of Solanum tuberosum that are also resistant to potato viruses $Y$ and $\mathrm{A}$ : evidence for a locus conferring broad-spectrum potyvirus resistance. Theoretical and Applied Genetics 95:1258-1262.

Barone, A., E. Ritter, U. Schachtschabel, T. Debener, F. Salamini, and C. Gebhardt. 1990. Localization by restriction fragment length polymorphism mapping in potato of a major dominant gene conferring resistance to the potato cyst nematode Globodera rostochiensis. Molecular Genetics and Genomics 224:177-182.

Bendahmane, A., K. Kanyuka, and D.C. Baulcombe. 1997. High resolution genetical and physical mapping of the $R x$ gene for extreme resistance to potato virus $\mathrm{X}$ in tetraploid potato. Theoretical and Applied Genetics 95:153-162.

Bendahmane, M., M. Koo, E. Karrer, and R.N. Beachy. 1999. Display of epitopes on the surface of tobacco mosaic virus: impact of charge and isoelectric point of the epitope on virus-host interactions. Journal of Molecular Biology 290:9-20.

Bertrand, C., Y. Collard, and D.J. Mackill. 2008. Marker-assisted selection: an approach for precision plant breeding in the twentyfirst century. Philosophical Transactions of the Royal Society B: Biological Sciences 363:557-572.

Brunt, A.A., K. Crabtree, M.J. Dallwitz, A.J. Gibbs, and L. Watson. 1996. Viruses of plants. 1484 p. CAB International, Wallingford, UK.

Bryan, G.J., K. McLean, J.E. Bradshaw, W.S. De Jong, M. Phillips, L. Castelli, et al. 2002. Mapping QTLs for resistance to the cyst nematode Globodera pallida derived from the wild potato species Solanum vernei. Theoretical and Applied Genetics 105:68-77.

Cockerham, G. 1943. Potato breeding for virus resistance. Annals of Applied Biology 30:105-108.

Cockerham, G. 1970. Genetical studies on resistance to potato viruses X and Y. Heredity 25:309-348.

Contreras, A., y J. Banse. 1982. Determinación de virus en el germoplasma chileno de papas (Solanum sp.) Agro Sur 10(2):84-89.

Contreras, A., y I. Castro. 2008. Catálogo de variedades de papas nativas de Chile. 236 p. Universidad Austral de Chile, Valdivia, Chile.

Contreras, A., y V. Tapia. 1983. Resistencia a virus en variedades antiguas de papa chilena (Solanum tuberosum L.) Agro Sur 11(2):69-73. 
Dalla Rizza, M., F. Vilaro, D.G. Torres, and D.C. Maeso. 2006. Detection of PVY extreme resistance genes in potato germplasm from the Uruguayan breeding program. American Journal of Potato Research 83:297-304.

Dalton, E., D. Griffin, T. Gallagher, N. De Vetten, and D. Milbourne. 2013. The effect of pyramiding two potato cyst nematode resistance loci to Globodera pallida $\mathrm{Pa} 2 / 3$ in potato. Molecular Breeding 31:921-930.

Doyle, J.J., and J.L. Doyle. 1990. Isolation of plant DNA from fresh tissue. Focus 12:13-15.

Gebhardt, C., D. Bellin, H. Henselewski, W. Lehmann, J. Schwarzfischer, and J.P. Valkonen. 2006. Marker-assisted combination of major genes for pathogen resistance in potato. Theoretical and Applied Genetics 112:1458-1464.

Gebhardt, C., and J.P.T. Valkonen. 2001. Organization of genes controlling disease resistance in the potato genome. Annual Review of Phytopathology 39:79-102.

Hawkes, J. 1990. The Potato, evolution, biodiversity and genetic resources. Belhaven Press, London, UK.

Jellis, G.J., and R.E. Boulton. 1984. Damage and loss caused by potato diseases p. 255-266, 327. In Wood, R.K.S., and G.J. Jellis (eds.) Plant diseases: Infection, damage and loss. Blackwell Scientific Publications, Oxford, UK.

Kasai, K., Y. Morikawa, V.A. Sorri, J.P.T. Valkonen, C. Gebhardt, and K.N. Watanabe. 2000. Development of SCAR markers to the PVY resistance gene $R y_{\text {adg }}$ based on a common feature of plant disease resistance genes. Genome 43:1-8.

Lindner, K., A. Behn, A. Schwarzfischer, und Y. Song. 2011. Extreme Y-Resistenz im aktuellen deutschen Kartoffelsortiment. Journal für Kulturpflanzen 63(4):97-103.

Lopez-Pardo, R., L. Barandalla, E. Ritter, and J. Ruiz De Galarreta. 2013. Validation of molecular markers for pathogen resistance in potato. Plant Breeding 132:246-251.

Milczarek, D., B. Flis, and A. Przetakiewicz. 2011. Suitability of molecular markers for selection of potatoes resistant to Globodera spp. American Journal of Potato Research 88:245-255.

Milla, A., y C. Krausz. 2004. Detección de resistencia al nematodo dorado (Globodera rostochiensis Woll) en accesiones pertenecientes al germoplasma chileno de papa (Solanum tuberosum L.) Agro Sur 32(1):28-34.

Mugniéry, D., and M.S. Phillips. 2007. The nematode parasites of potato. p. 569-594. In Vreugdenhil, D., J. Bradshaw, C. Gebhardt, F. Govers, M. Taylor, D. MacKerron, H. Ross (eds.) Potato biology and biotechnology. Advances and perspectives. Elsevier, Wageningen, The Netherlands.

Ortega, F., and C. Lopez-Vizcon. 2012. Application of molecular Marker-Assisted Selection (MAS) for disease resistance in a Practical Potato Breeding Programme. Potato Research 55:1-13.

Paal, J., H. Henselewsk, J. Muth, K. Meksem, C.M. Menéndez, F. Salamini, et al. 2004. Molecular cloning of the potato Grol-4 gene conferring resistance to pathotype Rol of the root cyst nematode Globodera rostochiensis, based on a candidate gene approach. Plant Journal 38:285-297.

Phillips, M.S. 1994. Inheritance of resistance to nematodes. p. 319337. In Bradshaw, J.E., and G.R. Mackay (eds.) Potato genetics. CAB International, Wallingford, UK.

Ritter, E., T. Debener, A. Barone, F. Salamini, and C. Gebhardt. 1991. RFLP mapping on potato chromosomes of two genes controlling extreme resistance to potato virus X (PVX). Molecular Genetics and Genomics 227:81-85.
Ritter, E., J.I. Ruiz de Galarreta, M. Hernandez, G. Plata, L. Barandalla, R. Lopez, et al. 2009. Utilization of SSR and cDNA markers for screening know QTLs for late blight (Phytophthora infestans) resistance in potato. Euphytica 170:77-86.

Ritter, E., J.I. Ruiz de Galarreta, H.J. van Eck, and I. Sanchez. 2008. Construction of a potato transcriptome map based on the cDNA-AFLP technique. Theoretical and Applied Genetics 116:1003-1013.

Ross, H. 1986. Potato breeding: Problems and perspectives. Advances in Plant Breeding. Fortschritte der Pflanzenzüchtung (Suppl 13). Paul Parey, Berlin und Hamburg, Germany.

SAG. 2008. Declara área libre de Globodera rostochiensis, Globodera pallida, Thecaphora solani (Angiosorus solani) y Ralstonia solanacearum (raza 3, biovar 2), al área comprendida por la Provincia de Arauco, VIII Región y la IX, X y XI Regiones. Modificada por Res. $n^{\circ} 890$ de 2006 y n ${ }^{\circ} 2.238$ de 2008. Servicio Agrícola y Ganadero (SAG), Santiago, Chile. Available at http:// www.sag.cl/sites/default/files/RES_2104_2003.pdf (accessed 08.04.2015)

Sagredo, B., M. Mathias, C. Barrientos, I. Acuña, J. Kalazich, and J. Rojas. 2009. Evaluation of a SCAR RYSC3 marker of the Ry $\mathrm{y}_{a d g}$ gene to select resistant genotypes to Potato virus $Y$ (PVY) in the INIA Potato Breeding Program. Chilean Journal of Agricultural Research 69:305-315.

Salazar, L.F. 1995. Los virus de la papa y su control. Centro Internacional de la Papa, Lima, Perú.

Sattarzadeh, A., U. Achenbach, J. Lübeck, J. Strahwald, E. Tacke, H.R. Hofferbert, et al. 2006. Single nucleotide polymorphism (SNP) genotyping as basis for developing a PCR-based marker highly diagnostic for potato varieties with high resistance to Globodera pallida pathotype Pa2/3. Molecular Breeding 18:301-318.

Schwarzfischer A.,A. Behn, J. Groth, M. Reichmann, A. Kellermann, and Y. Song. 2009. Marker-assisted selection in practical potato breeding - experience and outlook. Tagung Züchtung und Genressourcen gegen abiotische Stressfaktoren. Markergestützte Selektion in der Praxis. 24-26 November 2009. 81-85. RaumbergGumpenstein, Germany.

Song, Y.S., L. Hepting, G. Schweizer, L. Hartl, G. Wenzel, and A. Schwarzfisher. 2005. Mapping of extreme resistance to PVY $\left(R y_{\text {sto }}\right)$ on chromosome XII using anther-culture-derived primary dihaploid potato lines. Theoretical and Applied Genetics 111:879-887.

Song, Y., and A. Schwarzfischer. 2008. Development of STS markers for selection of extreme resistance $\left(R y_{\text {sto }}\right)$ to PVY and maternal pedigree analysis of extremely resistant cultivars. American Journal of Potato Research 85:159-170.

Valkonen, J.P.T., M.M. Kyle, and S.A. Slack. 1996. Comparison of resistance to potyviruses within Solanaceae: infection of potatoes with tobacco etch potyvirus and peppers with potato A and $\mathrm{Y}$ potyviruses. Annals of Applied Biology 129:25-38.

Veramendi, S., M. Baldelomar, A. Teran, y J. Gabriel. 2011. Marcadores moleculares asociados a genes/QTLs de resistencia para factores bióticos en nuevas variedades de papa (Solanum tuberosum L.) de Bolivia. Revista Latinoamericana de la Papa 16:209-232. 